\title{
The relationships among structure variables of larch forests in China
}

\author{
Wenjing Fang (1), Qing Zhao, Qiong Cai, Anwar Eziz, Guoping Chen, Yuhao Feng, Heng Zhang, Jiangling Zhu, \\ Chengjun Ji, Zhiyao Tang ${ }^{*}$ and Jingyun Fang ${ }^{*}$
}

\begin{abstract}
Background: Larch (Larix Mill.) forests are widely distributed in the upper parts of mountainous areas in China, playing vital roles in constructing mountain landscapes and maintaining mountain environments. Despite their importance, our knowledges on the large-scale patterns of structure characteristics and the relationships between different structure variables are unclear. In this paper, we investigated 155 plots from 11 natural larch forest types across the country to explore the biogeographic patterns of the structure characteristics and the allometric relationships between different structure variables for Chinese larch forests.
\end{abstract}

Results: The structure characteristics were significantly different among larch forest types. For different larch forest types, the power function fits the relationships between tree height and diameter at breast height (DBH), average DBH and stem density, and taper and stem density well, but with different exponents among larch forest types. The power exponents of the allometric relationships between tree height and DBH for different larch forest types varied from 0.61 to 0.93 (mean = $0.86)$ by standard major axis regression $(\mathrm{SMA})$, and from 0.51 to 0.78 (mean $=0.56$ ) by ordinary least square regression (OLS). The 50\%, 75\% and 95\% quantile regression (QR) and OLS indicated that the average DBH and taper of the L. gmelinii forests, L. gmelinii var. principis-rupprechtii forests, and L. sibirica forests were significantly correlated with stem density.

Conclusions: The relationship between tree height and DBH showed a power function relationship for all larch forest types in China, but with different exponents. Overall, stem density was negatively correlated with average DBH and taper. The Sect. Larix forests exhibited stand density effect. Our findings provide an important basis for recognizing the biogeographic patterns of structure factors and for the management of larch forests in China.

Keywords: Larch forests, Stand factor, Allometric relationship, Power function, Density effect and self-thinning

\section{Background}

Forest structure variables are closely related to forest productivity and dynamics (Enquist et al. 2009; Fang et al. 2012a, 2012b; Ali 2019). Local and regional studies have illustrated that different structure variables, such as stem density, tree height, diameter at breast height (DBH), taper (the ratio of average DBH to average height), and slenderness (a quotient related to taper), were strongly correlated with each other, mostly showing allometric relationships, such as those between tree height and DBH, stem density

\footnotetext{
*Correspondence: zytang@urban.pku.edu.cn; jyfang@urban.pku.edu.cn Department of Ecology, College of Urban and Environmental Science, and Key Laboratory for Earth Surface Processes of the Ministry of Education, Peking University, Beijing 100871, China
}

and average $\mathrm{DBH}$, and stem density and taper (Wang et al. 1998; Falster and Westoby 2005; Li et al. 2006; Pretzsch 2006; Comeau et al. 2010; Rivoire and Moguedec 2012; Masaka et al. 2013; Duncanson et al. 2015).

In particular, stand stem density significantly affects the structure variables of forests, according to the selfthinning theory (Reineke 1933; Kira et al. 1953; Satoo 1962; Yoda et al. 1963; Tadaki 1964; Drew and Flewelling 1977, 1979; Westoby 1984; Xue and Hagihara 1999, 2001; Enquist and Niklas 2001; Xue et al. 2015; Zhou and Lin 2018). During the self-thinning processes, the plant individual size increases and stem density decreases, following a negative linear model when both stem density and plant size were $\operatorname{logarithm}$ transformed, i.e., $\ln N \sim-1.605 \ln D_{a}$, 
where $N$ and $D_{a}$ are stem density and average $\mathrm{DBH}$, respectively (Reineke 1933). Several hypotheses have been proposed to explain the negative relationship. Among them, the $-3 / 2$ self-thinning rule (or, the Yoda's law) is the most acknowledged theory, which proposed a $-3 / 2$ power function relationship between the mean biomass and stem density based on the geometric similarity theory (i.e., $B_{a} \propto N^{-3 / 2}$, where $B_{a}$ is average biomass) (Yoda et al. 1963). The self-thinning rule has been tested by several studies, e.g., West et al. $(1997,1999)$ and Enquist et al. (1998), who used metabolic scaling theory to explain selfthinning from the viewpoint of bioenergetics. As proposed by the metabolic scaling theory, the exponent between stem density and plant size was -2 , and that between biomass and stem density was $-4 / 3$, respectively (i.e., $N \propto$ $D_{a}{ }^{-2}$, and $B_{a} \propto N^{-4 / 3}$ ) (West et al. 1997, 1999; Enquist et al. 1998). In addition to the biomass and plant size, the stem density also influenced the taper of the tree stems (Dean and Baldwin 1996; Dean et al. 2002; Sharma and Zhang 2004; Sharma and Parton 2009). However, little is known about the influence of stem density on the taper (Sharma and Zhang 2004; Sharma and Parton 2009).

Similar to the relationship between stem density and plant size, many models have also been proposed to fit the relationship between tree height and DBH for different species, even for different populations within a species (Navroodi et al. 2016). Among these models, the power function and its extended forms were most commonly employed (Ogawa 1969; Fang et al. 1993; Falster and Westoby 2005; Wang et al. 2006). Some suggested a constant exponent for this model across different species which is expected to be $2 / 3$ for adult trees (King et al. 2009), and some argued that the exponents may vary among different taxonomic groups (such as between angiosperms and gymnosperms) and life forms (such as between evergreen and deciduous plants) (Hulshof et al. 2015).

Larches (Larix Mill.) are light-demanding coniferous species tolerant to low-temperature, which were widely distributed in cool-temperate zones and in mountainous areas of temperate northern hemisphere, and they serve as timberline species in many mountains in northern, southwestern, and northeastern China (Cheng and Fu 1978; Li 1995; Liu et al. 2002a, 2002b; Li et al. 2009). In China, larch species generally form pure forests with large areas, and parts are mixed with other needle-leaved trees (Cheng and Fu 1978). Larch forests are sensitive to changes in climatic factors, such as temperature and water availability (Wu 1980; Cui et al. 1999; Carrer and Urbinati 2006; Dulamsuren et al. 2008). Although some studies on the community structure and allometric relationships have been performed in some larch forests at local scales (Wang et al. 2006; Fang et al. 2012b; Liu et al. 2017; Usoltsev et al. 2019), knowledge of their community structures and allometric relationships at the national scale is still lack in China.
Here, we explored the relationships among different structure variables of larch forests, i.e., between tree height and $\mathrm{DBH}$, between average $\mathrm{DBH}$ and stem density, and between taper and stem density, based on field measurements of natural larch forests across China. Specifically, we attempt to answer the following questions: (1) what are the relationships among different structure variables of larch forests, and (2) are these relationships consistent across the range of observed larch forest types in China?

\section{Methods}

\section{Study species and area}

According to the Flora of China (http://foc.iplant.cn/), there are 11 species and 3 varieties of Larix in China, including 2 cultivated species ( $L$. decidua and L. kaempferi). According to the morphological and genetic features, these species can be grouped into two sections, i.e. Sect. Larix and Sect. Multiseriales (Cheng and $\mathrm{Fu}$ 1978; Wei and Wang 2003). Except for L. decidua, the larches constitute the dominant species of larch forests in different areas of China.

In this study, we investigated natural larch dominated forests distributed in mountainous areas with latitudes of $27.10^{\circ}-52.86^{\circ} \mathrm{N}$, longitudes of $85.14^{\circ}-128.41^{\circ} \mathrm{E}$, and elevations of $387-4317 \mathrm{~m}$ (Fig. 1; Table S1), each with an area of $600 \mathrm{~m}^{2}$. The plots were selected to present natural forests without any apparent human disturbance such as thinning or harvesting, or natural disturbance such as fire or storm. For each plot, the species name, height and DBH of each tree were recorded (for details of the investigation methods, see Fang et al. 2009). In total, we investigated 155 plots with 9722 larch individuals and 1191 other trees, each contained more larch than other tree stems, with a larch stem density of more than 500 individuals per ha. These plots included 11 larch forest types, from two sections, i.e., Sect. Larix forests including L. gmelinii, L. gmelinii var. principis-rupprechtii, L. olgensis and L. sibirica forests, and Sect. Multiseriales forests including L. griffithii, L. himalaica, $L$. mastersiana, $L$. potaninii, $L$. potaninii var. australis, $L$. potaninii var. chinensis and $L$. speciosa forests. Thereinto, the plot numbers of L. olgensis, L. griffithii, L. himalaica, L. mastersiana, L. potaninii, and L. speciose forest were less than 10 (Table S1).

On average, the tree species richness, larch stem density, tree stem density and total basal area proportion of larch were 2.3, 1151.0 stems per ha, 1292.3 stems per ha and $93.0 \%$, respectively (Table S1). Given that larch trees were dominant in these plots, structure variables such as stem density were not limited by plot area, and the tree richness of plots were relatively low (Table S1), we used the dominant species density (i.e., larch density) to study 


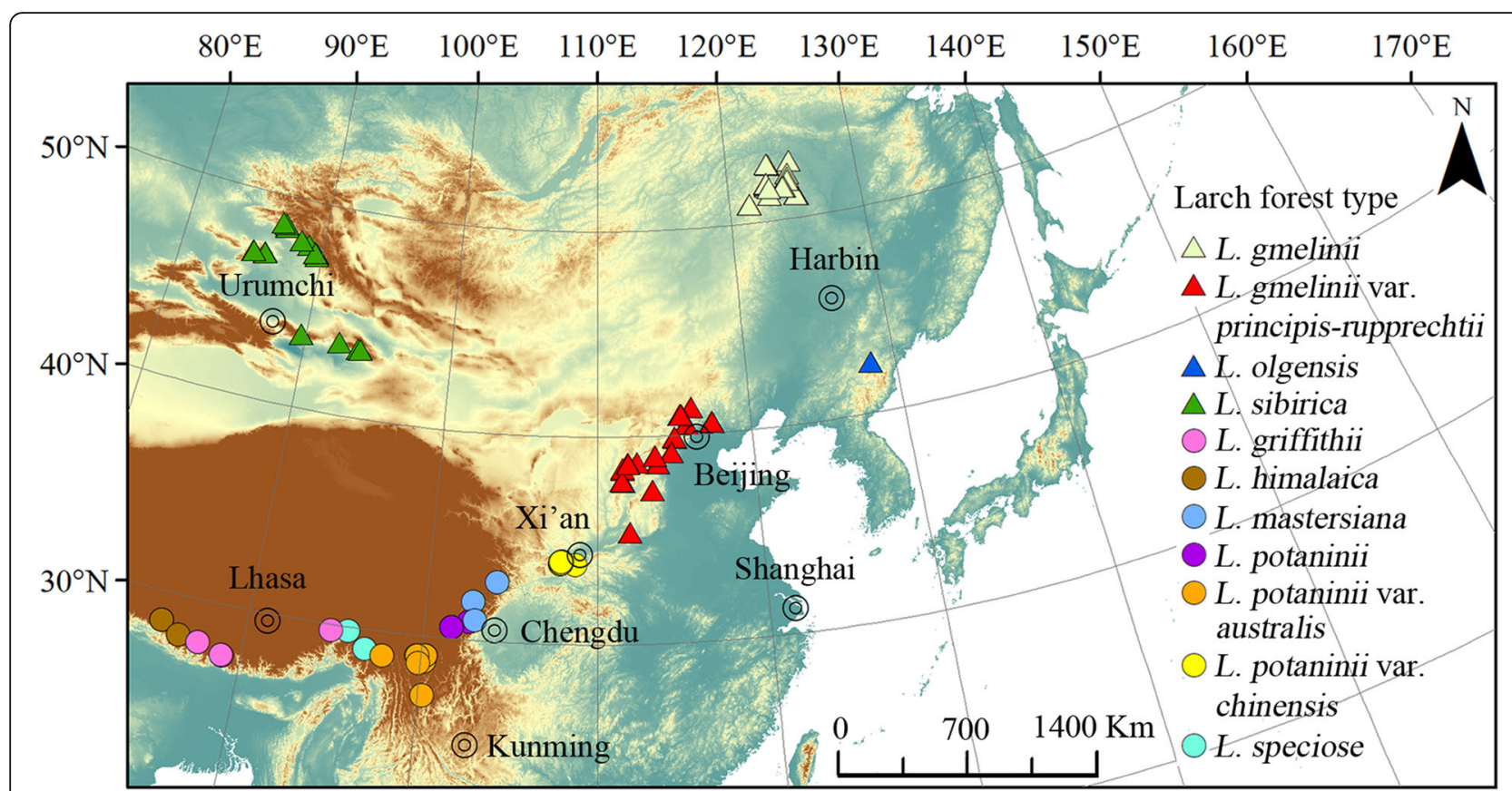

Fig. 1 Distribution of larch forest plots in China. Triangles indicate plots dominated by species from the Sect. Larix (Sect. Larix forests hereafter) and circles indicate plots dominated by species from the Sect. Multiseriales (Sect. Multiseriales forests hereafter)

the density effect of larch forests in China and did not consider the effects of other tree species.

\section{Data analysis}

According pervious research (Wang et al. 1998; West et al. 1999; Wang et al. 2006), we defined taper $\left(T, \mathrm{~cm} \cdot \mathrm{m}^{-1}\right)$ as the ratio of average DBH $\left(D_{\mathrm{a}}, \mathrm{cm}\right)$ to average height $\left(H_{\mathrm{a}}, \mathrm{m}\right)$ in a plot (Eq. 1), and slenderness $\left(\mathrm{S}, \mathrm{m} \cdot \mathrm{m}^{-1}\right)$ as one hundred times the ratio of $H_{\mathrm{a}}$ to $D_{\mathrm{a}}$ in a plot (Eq. 2).

$$
\begin{aligned}
& T=D_{\mathrm{a}} / H_{\mathrm{a}} \\
& S=100 \cdot H_{\mathrm{a}} / D_{\mathrm{a}}
\end{aligned}
$$

The following functions were applied to fit the relationship between height $(H)$ and DBH $(D)$ of trees (Eq. 3), average $\mathrm{DBH}\left(D_{\mathrm{a}}\right)$ and stem density (number of stems in a unit area, $N$ ) of plots (Eq. 4), and taper (T) and stem density of plots (Eq. 5).

$$
\begin{aligned}
& H=a \cdot D^{b} \\
& D_{\mathrm{a}}=k \cdot N^{d} \\
& T=e \cdot N^{f}
\end{aligned}
$$

where $b, d$ and $f$ are power exponent parameters and $a$, $k$ and $e$ are the proportionality constant parameters.

Many approaches have been proposed to fit the relationships between forest structure variables with logarithmically transformed data, such as ordinary least square regression (OLS), dimensionality reduction analysis, and quantile regression (QR) (Cade et al. 1999; Wilson et al. 1999; Li et al. 2006; Sun et al. 2010a). Here, all data were logarithmically transformed, parameters were estimated by OLS, and the relationship between tree height and DBH (Eq. 3) was also fitted with standard major axis regression (SMA). QR, with quantiles of $50 \%, 75 \%$ and $95 \%$, was employed to study the effect of stem density on average DBH and taper. The Eqs. 1-5 were calculated by individual larches per plot, respectively. For the 11 larch forest types, we calculated average structure variables, such as stem density, average DBH, average height, taper and slenderness, based on individual larch stem average of plot (Table S2). We compared the structure variables of different larch forest types by analysis of variance (ANOVA) and multiple comparisons with Bonferroni test, and marked the difference with letters.

Based on general linear model (GLM) and stepwise regression, we analyzed the effects of forest type, site and climatic factors on different structure variables of the larch forests. The site factors include longitude, latitude and altitude. The climatic factors are moisture index (MI, mm), mean annual temperature (MAT, $\left.{ }^{\circ} \mathrm{C}\right)$, mean temperature of the warmest month $\left(\mathrm{MTWM},{ }^{\circ} \mathrm{C}\right)$ and coldest month (MTCM, ${ }^{\circ} \mathrm{C}$ ) (for details on the climatic factors, see Table S3). According to Thornthwaite (1948), the MI is an index reflected the relationships among potential evapotranspiration, moisture surplus and moisture deficiency. 
All statistical analyses were performed in $\mathrm{R}$ (version 3.5.0) (R Core Team, 2018) with the "smatr" and "quantreg" packages (Warton et al. 2012; Koenker 2018).

\section{Results}

Statistics of the structure variables

The overall mean stem density, DBH, height, taper, and slenderness of larch forests in China were 1151.0 stems per ha (standard deviation $\mathrm{SD}=590.5), 16.5 \mathrm{~cm}(\mathrm{SD}=5.0), 12.0 \mathrm{~m}$ $(\mathrm{SD}=4.3), 1.5 \mathrm{~cm} \cdot \mathrm{m}^{-1}(\mathrm{SD}=0.6)$ and $75.6(\mathrm{SD}=27.4)$, respectively (Fig. 2; Table S2). With an average of 1287.6 stems per ha in stem density, $16.7 \mathrm{~cm}$ in DBH, $13.6 \mathrm{~m}$ in height,
$1.3 \mathrm{~cm} \cdot \mathrm{m}^{-1}$ in taper and 86.1 in slenderness, the Sect. Larix forests were denser, higher and slenderer than the Sect. Multiseriales forests (Fig. 2; Table S2). The structure variables varied significantly among larch forest types (Fig. 2). The stem density of the L. gmelinii forest was larger than that of the other Sect. Multiseriales forests, except the L. himalaica forest (Fig. 2a). The DBH of the L. potaninii var. chinensis forest was bigger than that of the L. gmelinii, L. griffithii, $L$. himalaica and L. potaninii forests (Fig. 2b). Most Sect. Larix forests was taller, while the taper was smaller, than that of the Sect. Multiseriales forests (Figs. 2c and d). The slenderness of the Sect. Multiseriales forests was bigger than 100, especially for L. gmelinii forest (Fig. 2e).

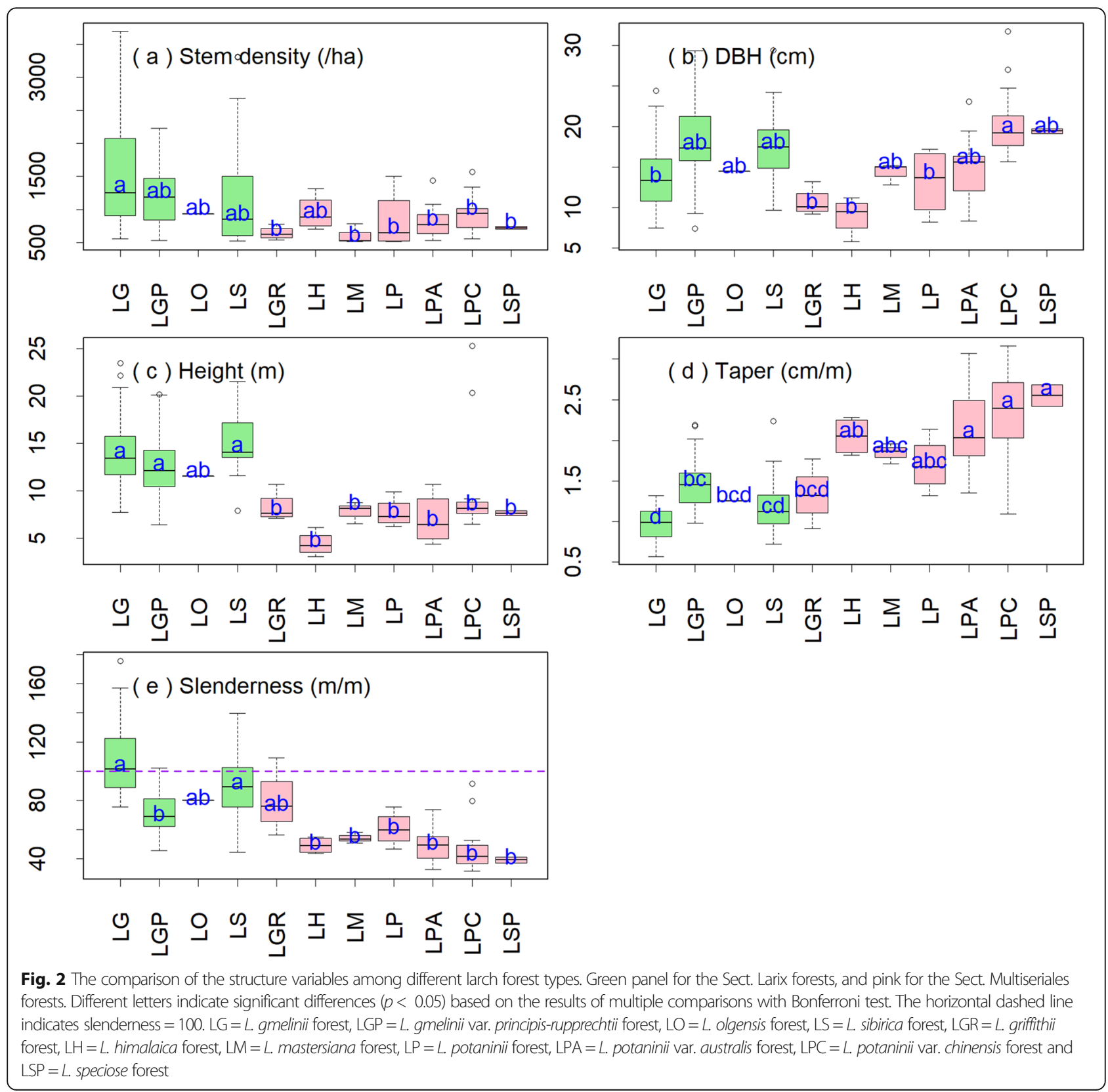


Table 1 The best regression model selected by forward stepwise regression for the structure variables of larch forests in China

\begin{tabular}{|c|c|c|c|c|c|}
\hline Variable & df & $F$-value & $p$-value & SS (\%) & $R^{2}$ of model \\
\hline \multicolumn{5}{|c|}{ Stem density $\left(\right.$ stem $\left.\cdot \mathrm{ha}^{-1}\right)$} & 0.15 \\
\hline Latitude & 1 & 27.91 & $<0.01$ & 15.43 & \\
\hline Residuals & 153 & & & 84.57 & \\
\hline \multicolumn{5}{|l|}{ Height (m) } & 0.48 \\
\hline Forest type & 10 & 11.68 & $<0.01$ & 42.91 & \\
\hline Longitude & 1 & 4.75 & $<0.05$ & 1.75 & \\
\hline Latitude & 1 & 2.21 & 0.14 & 0.81 & \\
\hline Altitude & 1 & 7.46 & $<0.01$ & 2.74 & \\
\hline Residuals & 141 & & & 51.79 & \\
\hline \multicolumn{5}{|l|}{ DBH (cm) } & 0.37 \\
\hline Forest type & 10 & 7.07 & $<0.01$ & 31.23 & \\
\hline Longitude & 1 & 8.57 & $<0.01$ & 3.79 & \\
\hline Altitude & 1 & 5.02 & $<0.05$ & 2.22 & \\
\hline Residuals & 142 & & & 62.76 & \\
\hline \multicolumn{5}{|l|}{ Taper $\left(\mathrm{cm} \cdot \mathrm{m}^{-1}\right)$} & 0.74 \\
\hline Forest type & 10 & 36.43 & $<0.01$ & 66.52 & \\
\hline Longitude & 1 & 1.45 & 0.23 & 0.26 & \\
\hline Latitude & 1 & 0.72 & 0.40 & 0.13 & \\
\hline Altitude & 1 & 40.25 & $<0.01$ & 7.35 & \\
\hline Residuals & 141 & & & 25.74 & \\
\hline
\end{tabular}

$\mathrm{df}, F$-value and SS (\%) are degree of freedom, $F$ statistical value and percentage of sum squares explained, respectively

\section{Factors impact the structure variables}

The GLM and stepwise regressions illustrated that forest type and site were the dominant factors influencing the structure variables (Table 1). Forest type was the most important factor for mean tree height (explaining $42.91 \%$ of the variation), DBH (31.23\%), and taper (66.52\%) (Table 1). The site variables only accounted for a minor part of the variations: e.g., altitude explained $2.74 \%$ for tree height, $2.22 \%$ for $\mathrm{DBH}$, and $7.35 \%$ for taper, while latitude explained as high as $15.43 \%$ for stem density (Table 1 ).

\section{Relationship among different structure variables}

Tree height and DBH showed a power function relationship (Fig. 3; Table 2). The SMA $b$-exponent between tree height and $\mathrm{DBH}$ was 0.86 (standard error $=0.01$ ) for overall plots, and it varied markedly among different larch forest types, with a range between 0.61 (L. potaninii forest) and 0.93 (L. griffithii forest); and the OLS $b$ exponent was 0.56 (standard error $=0.01$ ) for overall plots, with a range of 0.51 (L. potaninii forest) to 0.78 ( $L$. griffithii forest) (Table 2). The allometric relationships between height and DBH varied remarkably among larch forest types (Table S4). For example, both intercepts and slopes by SMA were significantly different among larch forest types (Fig. S1). In general, the $b$-exponents of the Sect. Multiseriales forests (SMA 0.83 and OLS 0.64) were greater than those of the Sect. Larix forests (SMA 0.74 and OLS 0.53) (Table 2).

The $d$-exponents for the relationship between average DBH and stem density were $-0.30,-0.33,-0.39$ and -0.43 for the OLS, the $50 \%, 75 \%$ and $95 \%$ quantiles, respectively (Fig. 4; Table 3). Among the 11 larch forest types, only the $L$. gmelinii $(-0.51,-0.50,-0.56$ and -0.49 for the OLS, the $50 \%, 75 \%$, and $95 \%$ quantiles, respectively), the L. gmelinii var. principis-rupprechtii $(-0.28,-0.33,-0.37$ and -0.53 for the OLS, the $50 \%, 75 \%$, and $95 \%$ quantiles, respectively) and the $L$. sibirica $(-0.38,-0.40,-0.48$ and -0.60 for the OLS, the $50 \%, 75 \%$, and $95 \%$ quantiles, respectively) forests exhibited a significant relationship between average DBH and stem density (Fig. 4; Table 3). The allometric relationships between average DBH and stem density were not different among larch forest types (Table S4). The Sect. Larix forests $(-0.44$, $-0.44,-0.50$ and -0.43 for the OLS, the $50 \%, 75 \%$, and $95 \%$ quantiles, respectively) exhibited a significant relationship between average DBH and stem density, while the Sect. Multiseriales forests did not show any significant correlations (Fig. 4; Table 3).

Taper and stem density showed a significant correlation for overall larch forests with $f$-exponents of -0.43 , $-0.47,-0.42$ and -0.70 for the OLS, the $50 \%, 75 \%$, and 95\% quantiles, respectively (Fig. 5; Table 4). The L. gmelinii $(-0.27,-0.29,-0.30$ and -0.19 for the OLS, the $50 \%, 75 \%$, and $95 \%$ quantiles, respectively), the L. gmelinii var. principis-rupprechtii (- 0.23 and -0.31 for the OLS and the 95\% quantile, respectively) and the L. sibirica $(-0.33,-0.27,-0.33$ and -0.53 for the OLS, the $50 \%, 75 \%$, and $95 \%$ quantiles, respectively) forests showed a significant relationship between taper and stem density (Fig. 5; Table 4). The allometric relationships between taper and stem density were not different among larch forest types (Table S4). The Sect. Larix forests $(-0.33,-0.33,-0.39$ and -0.37 for the OLS, the $50 \%, 75 \%$, and $95 \%$ quantiles, respectively) exhibited a significant relationship between average DBH and stem density (Fig. 5; Table 4).

\section{Discussion}

\section{Variation of structure variables among larch forest types}

Slenderness reflects forest stability, and greater slenderness indicates higher susceptibility of forest to disturbance (Wang et al. 1998; Masaka et al. 2013). In this study, we found greater slenderness for the Sect. Larix forests than for the Sect. Multiseriales forests (Fig. 2e). In this sense, the Sect. Larix forests were more sensitive to disturbance than the Sect. Multiseriales forests. The slenderness of the Sect. Larix forests was consistent with that reported in previous studies in Europe (Orzel 2007). 


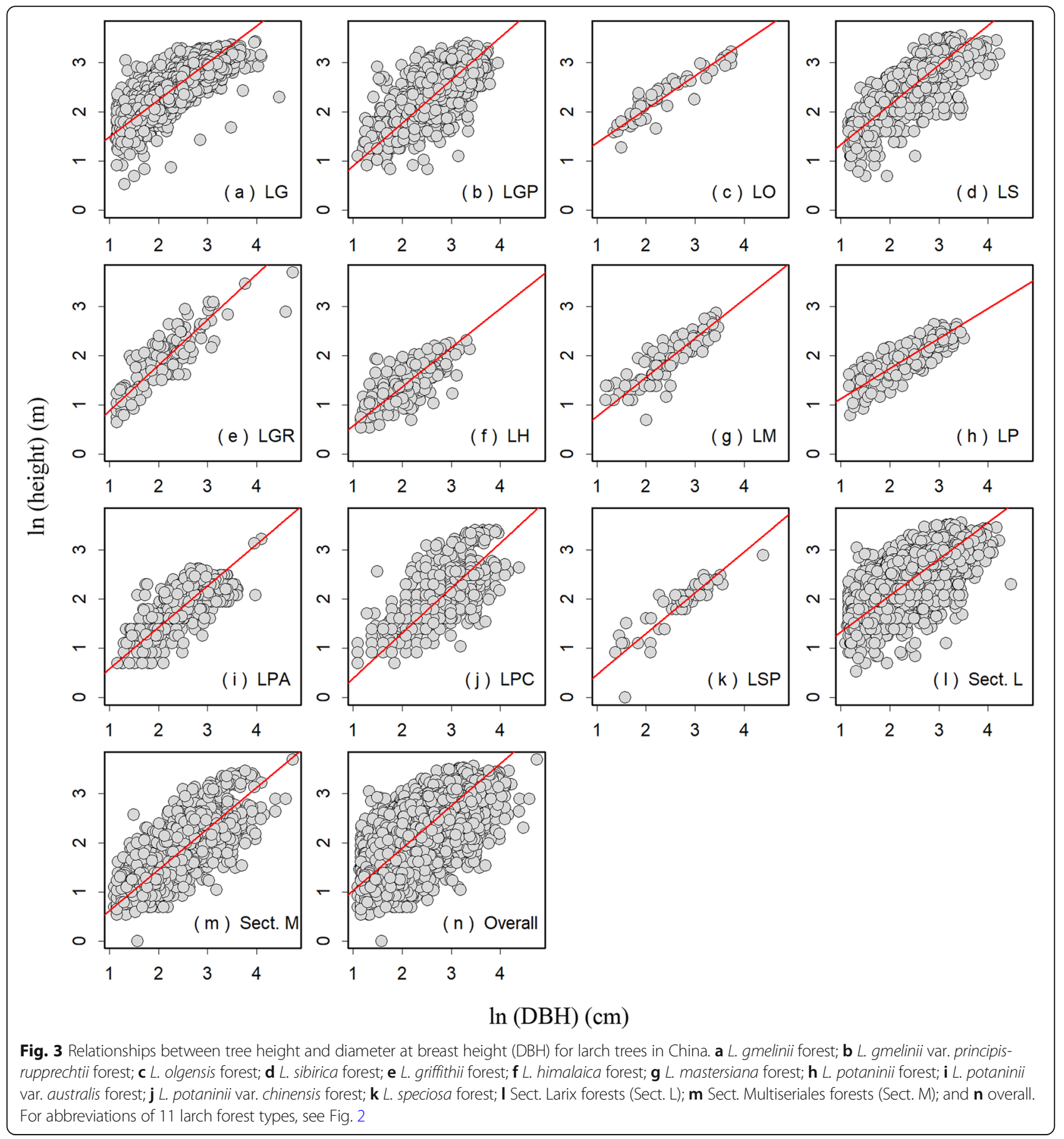

The structure variables varied remarkably among larch forest types (Fig. 2), partly because of the differences in the phenotypes of the dominant trees and site distributions of different larch forests (Figs. 1 and S2; Table 1). Forest type was the most important impact factor for all structure variables except the stem density (Table 1 ). Among the site factors, altitude was the main factor and latitude was the most important factor for the stem density (Table 1). All structure variables except the DBH exhibited significant geographic patterns (Fig. S2). Besides, stand age may influence the structure variables of different forest types (Chazdon et al. 2005), such as diameter of tree in the old-growth hemlock-hardwood forests (Tyrrell and Crow 1994), and DBH growth, height of branch and crown width in the Pinus sylvestris var. mongolica plantation (Zhou 2017). The absence of stand age in this study may limit the generalization of our conclusion. 
Table 2 Parameters of the standard major axis regression (SMA) and the ordinary least square regression (OLS) between tree height and DBH for larch forests in China

\begin{tabular}{|c|c|c|c|c|c|c|c|}
\hline \multirow[t]{2}{*}{ Forest type } & \multirow[t]{2}{*}{ No. of tree stems } & \multicolumn{3}{|l|}{ SMA } & \multicolumn{3}{|l|}{ OLS } \\
\hline & & $\ln (a)$ & $b$ & $R^{2}$ & $\ln (a)$ & $b$ & $R^{2}$ \\
\hline L. gmelinii & 3009 & $0.74 \pm 0.04$ & $0.75 \pm 0.01$ & $0.69^{* * *}$ & $1.03 \pm 0.02$ & $0.63 \pm 0.01$ & $0.69^{* *}$ \\
\hline L. gmelinii var. principis - rupprechtii & 3397 & $0.03 \pm 0.06$ & $0.87 \pm 0.02$ & $0.44^{* * *}$ & $0.85 \pm 0.03$ & $0.58 \pm 0.01$ & $0.44^{* *}$ \\
\hline L. olgensis & 56 & $0.70 \pm 0.17$ & $0.68 \pm 0.06$ & $0.87^{* * *}$ & $0.81 \pm 0.08$ & $0.63 \pm 0.03$ & $0.87^{* *}$ \\
\hline L. sibirica & 1205 & $0.53 \pm 0.07$ & $0.81 \pm 0.03$ & $0.66^{* * *}$ & $0.91 \pm 0.04$ & $0.66 \pm 0.01$ & $0.66^{* *}$ \\
\hline L. griffithii & 120 & $-0.05 \pm 0.21$ & $0.93 \pm 0.09$ & $0.71^{* * *}$ & $0.27 \pm 0.10$ & $0.78 \pm 0.05$ & $0.71^{* *}$ \\
\hline L. himalaica & 210 & $-0.23 \pm 0.17$ & $0.80 \pm 0.07$ & $0.49^{* * *}$ & $0.27 \pm 0.08$ & $0.56 \pm 0.04$ & $0.49^{* *}$ \\
\hline L. mastersiana & 101 & $-0.03 \pm 0.20$ & $0.79 \pm 0.07$ & $0.76^{* * *}$ & $0.23 \pm 0.10$ & $0.69 \pm 0.04$ & $0.76^{* *}$ \\
\hline L. potaninii & 183 & $0.52 \pm 0.12$ & $0.61 \pm 0.05$ & $0.71^{* * *}$ & $0.74 \pm 0.06$ & $0.51 \pm 0.02$ & $0.71^{* *}$ \\
\hline L. potaninii var. australis & 491 & $-0.26 \pm 0.13$ & $0.84 \pm 0.05$ & $0.58^{* * *}$ & $0.25 \pm 0.06$ & $0.64 \pm 0.02$ & $0.58^{* *}$ \\
\hline L. potaninii var. chinensis & 892 & $-0.53 \pm 0.12$ & $0.92 \pm 0.04$ & $0.53^{* * *}$ & $0.18 \pm 0.06$ & $0.67 \pm 0.02$ & $0.53^{* *}$ \\
\hline L. speciosa & 58 & $-0.36 \pm 0.29$ & $0.83 \pm 0.10$ & $0.79^{* * *}$ & $-0.10 \pm 0.14$ & $0.74 \pm 0.05$ & $0.79^{* *}$ \\
\hline Sect. Larix & 7667 & $0.59 \pm 0.03$ & $0.74 \pm 0.01$ & $0.51^{* * *}$ & $1.14 \pm 0.02$ & $0.53 \pm 0.01$ & $0.51^{* *}$ \\
\hline Sect. Multiseriales & 2055 & $-0.22 \pm 0.06$ & $0.83 \pm 0.02$ & $0.59^{* * *}$ & $0.28 \pm 0.03$ & $0.64 \pm 0.01$ & $0.59^{* *}$ \\
\hline Overall & 9722 & $0.16 \pm 0.03$ & $0.86 \pm 0.01$ & $0.42^{* * *}$ & $0.95 \pm 0.02$ & $0.56 \pm 0.01$ & $0.42^{* *}$ \\
\hline
\end{tabular}

The $a$ and $b$ are the parameters of Eq. 3 . Values represent estimate value \pm standard error. ${ }^{* * *}$ indicates that the $p$-value was less than 0.001

\section{The differences of exponents between tree height and DBH among larch forest types}

Inconsistent with King et al. (2009), we found that the $b$-exponent between tree height and DBH of overall larch forests in China was larger than $2 / 3$ for the SMA and equal to $2 / 3$ for the OLS (Tables 2 and S5).
However, the forest type dependence of the exponent was consistent with Wang et al. (2006) and LopezSerrano et al. (López-Serrano et al. 2005), who found that this relationship was significantly modulated by climate at a large scale. Similarly, Liu et al. (2017) found that the $b$-exponents between tree height and $\mathrm{DBH}$ of
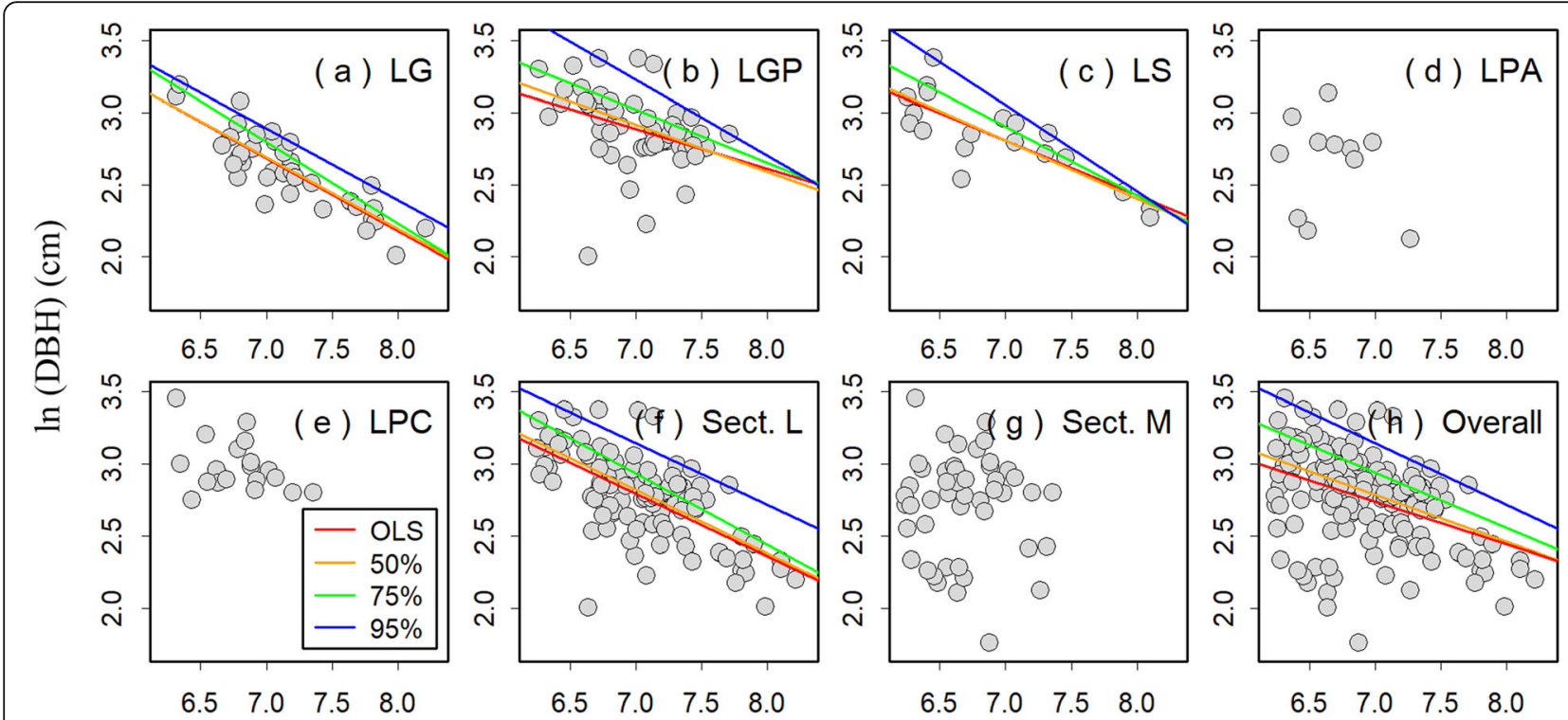

$\ln$ (stem density) (/ha)

Fig. 4 Relationships between average DBH and stem density for larch forest types with more than 10 plots in China according to the quantile regression (QR) with quantiles of 50\%, 75\% and $95 \%$ and the ordinary least square regression (OLS). a L. gmelinii forest; b L. gmelinii var. principisrupprechtii forest; $\mathbf{c}$ L. sibirica forest; $\mathbf{d}$ L. potaninii var. australis forest; $\mathbf{e}$ L. potaninii var. chinensis forest; $\mathbf{f}$ Sect. Larix forests; $\mathbf{g}$ Sect. Multiseriales forests; and $\mathbf{h}$ overall. For abbreviations of each larch forest type, see Figs. 2 and 3 
Table 3 Parameters of the quantile regression (QR) and the ordinary least square regression (OLS) between average DBH and stem density for larch forests in China

\begin{tabular}{|c|c|c|c|c|c|}
\hline \multirow[t]{2}{*}{ Forest type } & \multirow[t]{2}{*}{ No. of plots } & \multicolumn{4}{|c|}{ Exponent $d$ (mean \pm standard error) } \\
\hline & & OLS & $50 \%$ quantile & $75 \%$ quantile & $95 \%$ quantile \\
\hline L. gmelinii & 37 & $-0.51 \pm 0.05^{* *}$ & $-0.50 \pm 0.08^{* *}$ & $-0.56 \pm 0.07^{* *}$ & $-0.49 \pm 0.08^{* *}$ \\
\hline L. gmelinii var. principis - rupprechtii & 51 & $-0.28 \pm 0.10^{* *}$ & $-0.33 \pm 0.09^{* *}$ & $-0.37 \pm 0.08^{* *}$ & $-0.53 \pm 0.23^{*}$ \\
\hline L. olgensis a & 1 & - & - & - & - \\
\hline L. sibirica & 19 & $-0.38 \pm 0.07^{* *}$ & $-0.40 \pm 0.08^{* *}$ & $-0.48 \pm 0.11^{* *}$ & $-0.60 \pm 0.13^{* *}$ \\
\hline L. griffithii & 4 & $-0.35 \pm 0.68$ & $-0.13 \pm 1.16$ & $-1.15 \pm 1.74$ & $-1.15 \pm 2.04$ \\
\hline L. himalaica & 4 & $0.13 \pm 0.74$ & $0.42 \pm 1.15$ & $0.20 \pm 1.17$ & $0.20 \pm 1.09$ \\
\hline L. mastersiana & 3 & $0.16 \pm 0.36$ & $-0.03 \pm 4.73$ & $-0.03 \pm 4.82$ & $-0.03 \pm 5.11$ \\
\hline L. potaninii & 4 & $-0.38 \pm 0.40$ & $-0.33 \pm 0.89$ & $-0.40 \pm 0.99$ & $-0.40 \pm 0.97$ \\
\hline L. potaninii var. australis & 11 & $-0.25 \pm 0.36$ & $-0.19 \pm 0.59$ & $-0.28 \pm 0.60$ & $-1.01 \pm 0.87$ \\
\hline L. potaninii var. chinensis & 19 & $-0.25 \pm 0.15$ & $-0.13 \pm 0.23$ & $-0.49 \pm 0.31$ & $-0.30 \pm 0.47$ \\
\hline L. speciose ${ }^{a}$ & 2 & - & - & - & - \\
\hline Sect. Larix & 108 & $-0.44 \pm 0.05^{* *}$ & $-0.44 \pm 0.06^{* *}$ & $-0.50 \pm 0.06^{* *}$ & $-0.43 \pm 0.12^{* *}$ \\
\hline Sect. Multiseriales & 47 & $-0.05 \pm 0.17$ & $0.03 \pm 0.17$ & $-0.02 \pm 0.19$ & $-0.57 \pm 0.40$ \\
\hline Overall & 155 & $-0.30 \pm 0.05^{* *}$ & $-0.33 \pm 0.07^{* *}$ & $-0.39 \pm 0.06^{* *}$ & $-0.43 \pm 0.12^{* *}$ \\
\hline
\end{tabular}

The $d$ is the parameter of Eq. 4. aindicates larch forest types with the number of plots less than $3 .{ }^{* *}$ and ${ }^{*}$ indicate $p<0.01$ and $p<0.05$, respectively

larch forests were not only correlated with larch forest type, but also significantly affected by MAT. Climatic conditions are very important for tree growth (Littell et al. 2008; Fang et al. 2012a, 2012b). Trees tend to grow vertically under warm and humid climatic conditions, while they tend to grow radially under cold climatic conditions (Wang et al. 2006; Liu et al. 2017; Littell et al. 2008). Hence, the relationship between height and DBH differs among climatic conditions. For different larch forests, climate factors also significantly influence tree growth (Carrer and Urbinati 2006; Dulamsuren et al. 2008, 2010, 2011). For example, Dulamsuren et al.

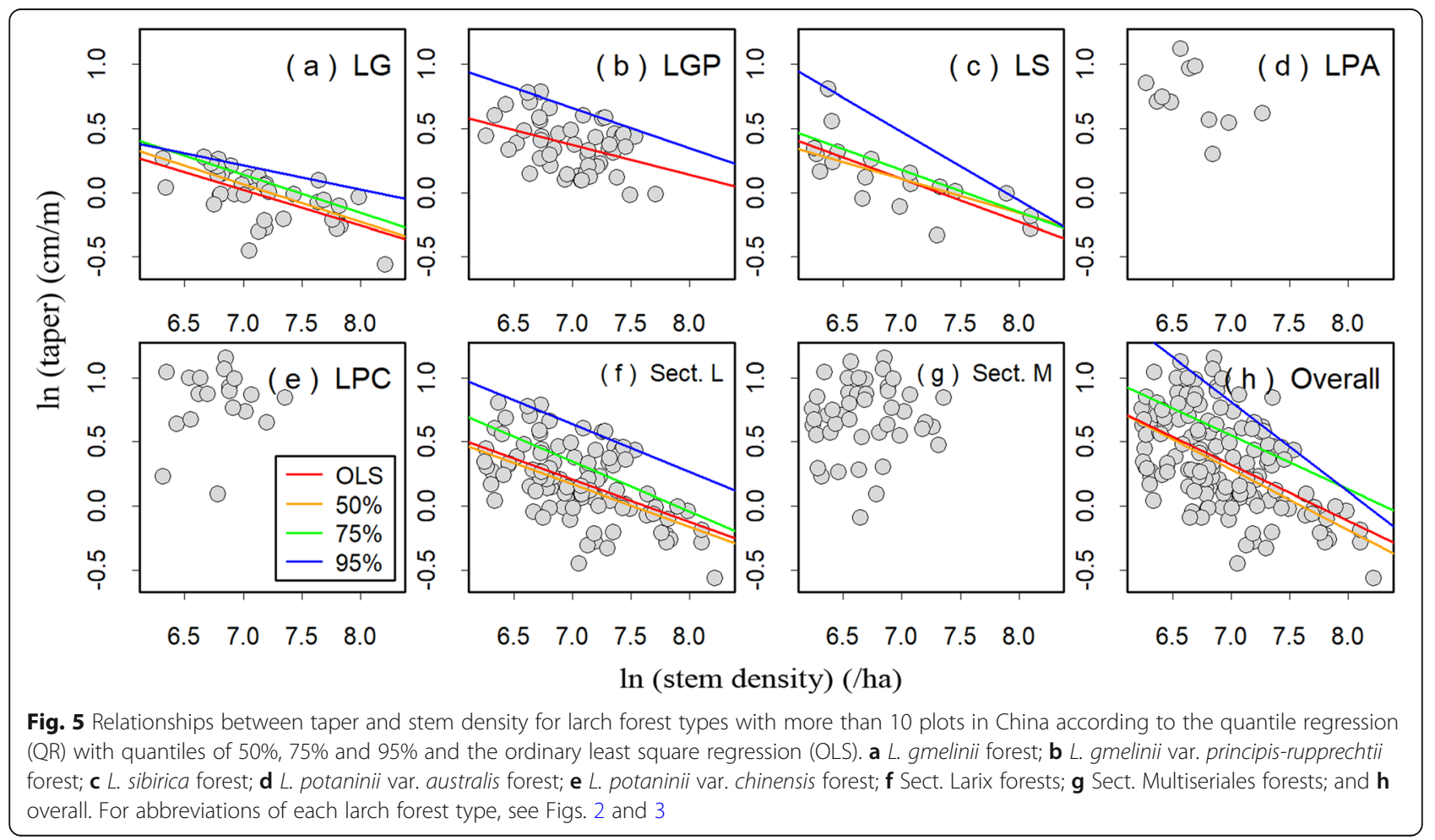


Table 4 The parameters of the quantile regression (QR) and the ordinary least square regression (OLS) between taper and stem density for larch forests in China

\begin{tabular}{|c|c|c|c|c|}
\hline \multirow[t]{2}{*}{ Forest type } & \multicolumn{4}{|c|}{ Exponent $f($ mean \pm standard error) } \\
\hline & OLS & $50 \%$ quantile & $75 \%$ quantile & $95 \%$ quantile \\
\hline L. gmelinii & $-0.27 \pm 0.06^{* *}$ & $-0.29 \pm 0.09^{* *}$ & $-0.30 \pm 0.06^{* *}$ & $-0.19 \pm 0.05^{* *}$ \\
\hline L. gmelinii var. principis -rupprechtii & $-0.23 \pm 0.08^{* *}$ & $-0.12 \pm 0.12$ & $-0.18 \pm 0.10$ & $-0.31 \pm 0.09^{* *}$ \\
\hline L. olgensis ${ }^{a}$ & - & - & - & - \\
\hline L. sibirica & $-0.33 \pm 0.07^{* *}$ & $-0.27 \pm 0.07^{* *}$ & $-0.33 \pm 0.11^{* *}$ & $-0.53 \pm 0.12^{* *}$ \\
\hline L. griffithii & $-1.31 \pm 0.83$ & $-1.83 \pm 1.68$ & $-2.55 \pm 2.05$ & $-2.55 \pm 1.98$ \\
\hline L. himalaica & $-0.38 \pm 0.14$ & $-0.32 \pm 0.28$ & $-0.46 \pm 0.32$ & $-0.46 \pm 0.35$ \\
\hline L. mastersiana & $-0.27 \pm 0.11$ & $-0.21 \pm 1.30$ & $-0.34 \pm 1.62$ & $-0.34 \pm 1.56$ \\
\hline L. potaninii & $-0.18 \pm 0.25$ & $-0.07 \pm 1.20$ & $-0.26 \pm 1.48$ & $-0.26 \pm 1.12$ \\
\hline L. potaninii var. australis & $-0.35 \pm 0.24$ & $-0.35 \pm 0.32$ & $-0.56 \pm 0.49$ & $-0.72 \pm 0.69$ \\
\hline L. potaninii var. chinensis & $0.14 \pm 0.23$ & $-0.05 \pm 0.28$ & $-0.20 \pm 0.27$ & $0.21 \pm 0.38$ \\
\hline L. speciose ${ }^{a}$ & - & - & - & - \\
\hline Sect. Larix & $-0.33 \pm 0.05^{* *}$ & $-0.33 \pm 0.04^{* *}$ & $-0.39 \pm 0.11^{* *}$ & $-0.37 \pm 0.09^{* *}$ \\
\hline Sect. Multiseriales & $0.06 \pm 0.14$ & $0.05 \pm 0.15$ & $0.03 \pm 0.22$ & $0.05 \pm 0.25$ \\
\hline Overall & $-0.43 \pm 0.06^{* *}$ & $-0.47 \pm 0.06^{* *}$ & $-0.42 \pm 0.10^{* *}$ & $-0.70 \pm 0.20^{* *}$ \\
\hline
\end{tabular}

The $f$ is the parameter of Eq. $5 .{ }^{~}$ indicates larch forest types with the number of plots less than $3 .{ }^{* *}$ and ${ }^{*}$ indicate $p<0.01$ and $p<0.05$, respectively

(2010, 2011) found that the tree-ring width of L. sibirica was positively related to warm and humid climatic conditions and that aridity reduced the growth of this species. Zhang et al. (2013) found that average DBH and stem density of the L. gmelinii in northeastern China were largely determined by precipitation of the driest quarter. Bhatta et al. (2018) found that radial growth of the L. griffithii was significantly positively correlated with the precipitation of the wettest quarter and negatively correlated with the mean temperature of the warmest month in Nepal near the Tibetan Plateau. Meanwhile, the growth response of larch to climatic conditions depends on altitude (Sun et al. 2010b). In this study, the differences in site and climatic conditions among larch forest types (Figs. 1 and S2) resulted in markedly different tree heightDBH relationships. The $b$-exponent of overall larch forests was consistent with the result of Liu et al. (2017) (0.56 vs. 0.51) at the national scale. However, in contrast to our study (Table 2), Liu et al. (2017) found that the $b$-exponents between tree height and $\mathrm{DBH}$ of Sect. Larix forests in northeastern China $(0.65 \pm 0.11$ for the L. gmelinii forest and $0.68 \pm 0.10$ for the L. olgensis forest) were significant bigger than those of the Sect. Multiseriales forests in southwestern China (L. mastersiana forest: $0.51 \pm 0.17$ and L. potaninii forest: $0.54 \pm 0.15$ ), partly because of their limited number of forest types. In their studies, Liu et al. (2017) included only four forest types, while we included seven forest types dominated by the species from the Sect. Multiseriales.

\section{Site condition and self-thinning of larch forests in China}

Gradel et al. (2017) found that thinning significantly increased the growth of larch. In other words, low stem density is conducive to the growth of larch. This finding is consistent with our result regarding the stem density effect. There were significant negative power function relationships between average DBH and stem density, and between taper and stem density for overall larch forests and the Sect. Larix larch forests in China (Tables 3 and 4). However, the results varied among forest types. The L. gmelinii, the L. gmelinii var. principis-rupprechtii and the L. sibirica forests, all belonging to the Sect. Larix forests, showed a significant negative power function relationship, while the other types did not exhibit significant relationship (Figs. 2 and 3). Compared with the Sect. Larix forests, the Sect. Multiseriales forests suffered more environmental stress and their densities were comparatively low (average stem density: 605.8-945.7 stems per ha) and even did not result in natural thinning. For example, the Sect. Multiseriales forests are distributed in the alpine regions of southwestern China, with a mean elevation of over $3000 \mathrm{~m}$, and some are even distributed in the frigid areas at an elevation over $4000 \mathrm{~m}$ (Fig. S2) (Cheng and Fu 1978; Wu 1980). Therefore, environmental conditions of the Sect. Multiseriales forests are generally more stressful (Cheng and Fu 1978; Wu 1980). For woody plant communities, site conditions would commonly affect the natural thinning process (Fang 1992). Compared with that of conifer forests distributed at lower altitudes, crown density of the Sect. Multiseriales 
forests was lower (average stem density: 837.0 stems per ha). Some of these forests were even sparse forests, and self-thinning may not have occurred. Therefore, the effect of density was less obvious for the Sect. Multiseriales forests. This finding is consistent with the results of Comeau et al. (2010), who found that the relationship between stem density and average DBH was influenced by environmental and other factors, and indicated the need to elucidate the relationship between stem density and average DBH for different forest types and for different regions where the forest types grow.

The exponents of average DBH vs. stem density relationship and taper vs. stem density relationship differed greatly among forest types and varied between different approaches (QR vs. OLS). Although there were few literatures of allometric relationships between density and other structure variables about larch forests, dependence of the exponent on forest type was also observed for other coniferous forests. For example, Cui et al. (2016) found that the exponent between stem density and average DBH for the Cunninghamia lanceolata plantations was not constant but obeyed a normal distribution with an average of 1.88. Rivoire and Moguedec (2012) found that the exponents varied from -1.59 by a stochastic frontier function to -1.85 by a generalized optimization method. Pretzsch (2006) found that the exponents between stem density and average $\mathrm{DBH}$, and between biomass and stem density were not constant, but were related to forest types. These results, together with ours, indicated that the power exponents of structure variables vs. stem density relationship tended to vary with forest types and depended on the analytical methods (Sun et al. 2010a; Cui et al. 2016). The site conditions differed among larch forest types, which were distributed in different regions (Fig. 1). Site conditions are commonly found to affect the natural thinning process in woody plant communities (Fang 1992). Therefore, the exponents between average $\mathrm{DBH}$ and stem density, and between taper and stem density for larch forests were not constant and varied with larch forest types.

\section{Conclusions}

In this study, we explored the relationships among structure variables of larch forests in China based on an extensive investigation of natural larch forest across China. We found that the Sect. Larix forests were denser, taller and slenderer than the Sect. Multiseriales forests. The relationship between tree height and DBH showed a power function relationship for all larch forest types, but they had different exponents. Overall, stem density was negatively correlated with average $\mathrm{DBH}$ and taper.
Among the 11 larch forest types, stem density was negatively correlated with DBH and taper of the L. gmelinii, the L. gmelinii var. principis-rupprechtii and the L. sibirica forests, but not for other types. We concluded that all structure variables except stem density were forest type dependent. The exponents between tree height and $\mathrm{DBH}$, average $\mathrm{DBH}$ and stem density, and taper and stem density for larch forests varied among larch forest types. The Sect. Larix forests exhibited significant density effects.

\section{Supplementary Information}

The online version contains supplementary material available at https://doi. org/10.1186/s40663-020-00273-w.

Additional file 1.

Abbreviations

DBH: Diameter at breast height; GLM: General linear model; MAT: Mean annual temperature; MI: Moisture index; MTCM: Mean temperature of the coldest month; MTWM: Mean temperature of the warmest month;

OLS: Ordinary least square regression; QR: Quantile regression; SMA: Standard major axis regression

\section{Acknowledgements}

We are grateful to Li Lanqing, Ma Guangming, Xu Qibiao and many others and the local forestry bureau for their assistance during the field investigation and to Guo Yanpei and Ma Suhui for their help in data analyses.

\section{Authors' contributions}

JF designed the research; WF, QZ, QC, GC, YF, HZ, CJ, ZT, and JF performed the field work; WF conducted the analysis; WF, ZT, JF and all the others contributed the writing of the manuscript. The author(s) read and approved the final manuscript.

\section{Funding}

This study was supported by the National Science and Technology Basic Project of China (No. 2015FY210200) and National Natural Science

Foundation (No. 31988102).

\section{Availability of data and materials}

The datasets used and/or analyzed during the current study are available from the corresponding author on reasonable request.

Ethics approval and consent to participate

Not applicable.

Consent for publication

Not applicable.

\section{Competing interests}

The authors declare that they have no competing interests.

Received: 9 June 2020 Accepted: 21 October 2020

Published online: 15 November 2020

\section{References}

Ali A (2019) Forest stand structure and functioning: current knowledge and future challenges. Ecol Indic 98:665-677

Bhatta S, Man KD, Aryal PC, Chauhan R, Dawadi B (2018) Climate variability and associated response of Larix griffithii in Kanchenjunga conservation area of Nepal. Appl Ecol Environ Sci 6(1):23-30

Cade BS, Terrell JW, Schroeder RL (1999) Estimating effects of limiting factors with regression quantiles. Ecology 80:311-323 
Carrer M, Urbinati C (2006) Long-term change in the sensitivity of tree-ring growth to climate forcing in Larix decidua. New Phytol 170(4):861-871

Chazdon RL, Brenes AR, Alvarado BV (2005) Effects of climate and stand age on annual tree dynamics in tropical second-growth rain forests. Ecology 86(7): 1808-1815

Cheng WC, Fu LK (1978) Flora Reipublicae Popularis Sinicae Gymnospermae. Science Press, Beijing, pp 169-196

Comeau PG, White M, Kerr G, Hale SE (2010) Maximum density-size relationships for Sitka spruce and coastal Douglas-fir in Britain and Canada. Forestry 83(5): 461-468

Cui HT, Dai JH, Tang ZY, Huang YM, Cao YL (1999) Stability of alpine timberline ecotone on Taibai Mountain China. J Environ Sci 11(2):207-210

Cui L, Zhang X, Duan A, Zhang J (2016) A hierarchical Bayesian model to predict maximum-size density line for Chinese fir plantation in southern China. Sci Silv Sin 52(9):95-102

Dean TJ, Baldwin VC (1996) The relationship between Reineke's stand-density index and physical stem mechanics. For Ecol Manag 81(1-3):25-34

Dean TJ, Roberts S, Gilmore D, Maguire DA, Long JN, O'hara KL, Seymour RS (2002) An evaluation of the uniform stress hypothesis based on stem geometry in selected north American conifers. Trees 16(8):559-568

Drew TJ, Flewelling JW (1977) Some recent Japanese theories of yield-density relationships and their application to Monterey pine plantations. For Sci 23(4):517-534

Drew TJ, Flewelling JW (1979) Stand density management: an alternative approach and its application to Douglas-fir plantations. For Sci 25(3):518-532

Dulamsuren C, Hauck M, Bader M, Osokhjargal D, Oyungerrl S, Nyambayar S, Runge M, Leuschner C (2008) Water relations and photosynthetic performance in Larix sibirica growing in the forest-steppe ecotone of northern Mongolia. Tree Physiol 29(1):99-110

Dulamsuren C, Hauck M, Leuschner C (2010) Recent drought stress leads to growth reductions in Larix sibirica in the western Khentey Mongolia. Glob Change Biol 16(11):3024-3035

Dulamsuren C, Hauck M, Leuschner H, Leuschner C (2011) Climate response of tree-ring width in Larix sibirica growing in the drought-stressed forest-steppe ecotone of northern Mongolia. Ann For Sci 68:275-282

Duncanson LI, Dubayah RO, Enquist BJ (2015) Assessing the general patterns of forest structure: quantifying tree and forest allometric scaling relationships in the United States. Glob Ecol Biogeogr 24(12):1465-1475

Enquist BJ, Brown JH, West GB (1998) Allometric scaling of plant energetics and population density. Nature 395:163-165

Enquist BJ, Niklas KJ (2001) Invariant scaling relations across tree-dominated communities. Nature 410(6829):655-660

Enquist BJ, West GB, Brown JH (2009) Extensions and evaluations of a general quantitative theory of forest structure and dynamics. Proc Natl Acad Sci U S A 106(17):7046-7051

Falster DS, Westoby M (2005) Alternative height strategies among 45 dicot rain forest species from tropical Queensland, Australia. J Eco 93(3):521-535

Fang JY (1992) The self-thinning rule of plant community. J Ecol Rural Environ $8(2): 7-12$

Fang JY, Liu GH, Zhang SH (1993) Relationship between tree height and diameter and its biological significance in a woody plant population. Chin $J$ Bot 5:77-82

Fang JY, Shen ZH, Tang ZY, Wang XP, Wang ZH, Feng JM, Liu YN, Qiao XJ, Wu $X P$, Zheng CY (2012a) Forest community survey and the structural characteristics of forests in China. Ecography 35:1059-1071

Fang JY, Wang XP, Liu YN, Tang ZY, White PS, Sanders NJ (2012b) Multi-scale patterns of forest structure and species composition in relation to climate in Northeast China. Ecography 35:1072-1082

Fang JY, Wang XP, Shen ZH, Tang ZY, He JS, Yu D, Jiang Y, Wang ZH, Zheng CY, Zhu JL, Guo ZD (2009) Methods and protocols for plant community inventory. Biodivers Sci 17(6):533-548

Gradel A, Ammer C, Ganbaatar B, Nodaldorj O, Dovdondemberel B, Wagner S (2017) On the effect of thinning on tree growth and stand structure of white birch (Betula platyphylla Sukaczev) and Siberian larch (Larix sibirica Ledeb.) in Mongolia. Forests 8(4):105. https://doi.org/10.3390/f8040105

Hulshof CM, Swenson NG, Weiser MD (2015) Tree height-diameter allometry across the United States. Ecol Evol 5(6):1193-1204

King DA, Davies SJ, Tan S, Noor NSM (2009) Trees approach gravitational limits to height in tall lowland forests of Malaysia. Funct Ecol 23:284-291
Kira T, Ogawa H, Sakazaki N (1953) Intraspecific competition among higher plants. I Competition-yield-density interrelationships in regularly dispersed populations J Inst Polytech Osaka City Univ Ser 4:1-16

Koenker R (2018) Quantreg: Quantile Regression. R package version 5, p 38 https://CRAN.R-project.org/package=quantreg. Accessed 10 Oct 2020

Li G, Shen ZH, Ying TS, Fang JY (2009) The spatial pattern of species richness and diversity centers of gymnosperm in China. Biodivers Sci 17(3):272-279

Li HT, Han XG, Wu JG (2006) Variant scaling relationship for mass-density across tree-dominated communities. J Integrat Plant Biol 48(3):268-277

Li N (1995) Studies on the geographic distribution origin and dispersal of the family Pinaceae Lindl. Acta Phytotaxon Sin 33:105-130

Littell J, Peterson D, Tjoelker M (2008) Douglas-fir growth in mountain ecosystems: water limits tree growth from stand to region. Ecol Monogr 78(3):349-368

Liu CY, Fang WJ, Cai Q, Ma SH, Ji CJ, Fang JY (2017) Allometric relationship between tree height and diameter of larch forests in China. Acta Sci Nat Univ Pekin 53(6):1081-1088

Liu HY, Tang ZY, Dai JH, Tang YX, Cui HT (2002a) Larch timberline and its development in North China. Mt Res Dev 22(4):359-367

Liu ZL, Fang JY, Piao SL (2002b) Geographical distribution of species genera Abies, Picea and Larix in China. Acta Geograph Sin 57:577-586

López-Serrano FR, García-Morote A, Andrés-Abellán M, Tendero A, Cerro AD (2005) Site and weather effects in allometries: a simple approach to climate change effect on pines. For Ecol Manag 215(1-3):251-270

Masaka K, Sato H, Torita H, Kon H, Fukuchi M (2013) Thinning effect on height and radial growth of Pinus thunbergii Parlat. Trees with special reference to trunk slenderness in a matured coastal forest in Hokkaido Japan. J For Res 18:475-481

Navroodi IH, Alavi SJ, Ahmadi MK, Radkarimi M (2016) Comparison of different non-linear models for prediction of the relationship between diameter and height of velvet maple trees in natural forests (case study: Asalem forests Iran). J For Sci 62:65-71

Ogawa H (1969) An attempt at classifying forest types based on the relationship between tree height and DBH. In: Kira T (ed) Comparative study of primary productivity in Forest ecosystems. JBBP-PT-F Progress reports for 1968, pp 3-17

Orzel S (2007) A comparative analysis of slenderness of the main tree species of the niepolomice forest. EJPAU 10(2) \#13. http://www.ejpau.media.pl/volume1 0/issue2/art-13.html. Accessed 10 Oct 2020

Pretzsch H (2006) Species-specific allometric scaling under self-thinning: evidence from long-term plots in forest stands. Oecologia 146(4):572-583

R Core Team (2018) R: a language and environment for statistical computing. R Foundation for Statistical Computing, Vienna. https://www.r-project.org/.

Reineke LH (1933) Perfecting a stand-density index for even-aged forests. J Agric Res 46(1):627-638

Rivoire M, Moguedec GL (2012) A generalized self-thinning relationship for multispecies and mixed-size forests. Ann For Sci 69(2):207-219

Satoo T (1962) Notes on Reineke's formulation of the relation between average diameter and density of stands. J Jap For Soc Tokyo 44:343-349

Sharma M, Parton J (2009) Modeling stand density effects on taper for Jack pine and black spruce plantations using dimensional analysis. For Sci 55(3):268-282

Sharma M, Zhang SY (2004) Variable-exponent taper equations for jack pine black spruce and balsam fir in eastern Canada. For Ecol Manag 198(1-3):39-53

Sun HG, Zhang JG, Duan AG (2010a) A comparison of selecting data points and fitting coefficients methods for estimating self-thinning boundary line. Chin J Plant Ecol 34:409-417

Sun Y, Wang LL, Chen J, Duan JP, Shao XM, Chen KL (2010b) Growth characteristics and response to climate change of Larix miller tree-ring in China. Sci China Earth Sci. https://doi.org/10.1007/s11430-010-0056-5

Tadaki Y (1964) Effect of thinning on stem volume yield studied with competition-density effect. Gov For Exp Stn Tokyo Bull 166:1-22

Thornthwaite CW (1948) An approach toward a rational classification of climate. Geogr Rev 38(1):55-94

Tyrrell LE, Crow TR (1994) Structural characteristics of old-growth hemlockhardwood forests in relation to age. Ecology 75(2):370-386

Usoltsev V, Danilin I, Tsogt Z, Osmirko A, Tsepordey I, Chasovskikh V (2019) Aboveground biomass of Mongolian larch (Larix sibirica Ledeb.) forests in the Eurasian region. GES 12(3):117-132. https://doi.org/10.24057/2071-9388-2018-70

Wang XP, Fang JY, Tang ZY, Zhu B (2006) Climatic control of primary forest structure and $\mathrm{DBH}$-height allometry in Northeast China. For Ecol Manag 234(1):264-274 
Wang Y, Titus SJ, Lemay VM (1998) Relationships between tree slenderness coefficients and tree or stand characteristics for major species in boreal mixed wood forests. Can J For Res 28(8):1171-1183

Warton D, Duursma R, Falster D, Taskinen S (2012) Smatr 3 - an R package for estimation and inference about allometric lines. Methods Ecol Evol 3:257-259

Wei X, Wang X (2003) Phylogenetic split of Larix: evidence from paternally inherited cpDNA trnT-trnF region. Plant Syst Evol 239(1-2):67-77

West GB, Brown JH, Enquist BJ (1997) A general model for the origin of allometric scaling laws in biology. Science 276:122-126

West GB, Brown JH, Enquist BJ (1999) A general model for the structure and allometry of plant vascular systems. Nature 400(6745):664-667

Westoby M (1984) The self-thinning rule. Adv Ecol Res 14(2):167-225

Wilson DS, Seymour RS, Maguire DA (1999) Density management diagram for northeastern red spruce and balsam fir forests. North J Appl For 16(1):48-56

Wu ZY (ed) (1980) Vegetation of China. Science Press, Beijing

Xue L, Hagihara A (1999) Density effect, self-thinning and size distribution in Pinus densiflora Sieb. Et Zucc. Stands. Ecol Res 14(1):49-58

Xue L, Hagihara A (2001) Summary and evaluation of the researches on selfthinning pure stands. Acta Ecol Sin 21(5):834-838

Xue L, Hou XL, Li Q, Hao LT (2015) Self-thinning lines and allometric relation in Chinese fir (Cunninghamia lanceolata) stands. J For Res 26(2):281-290

Yoda K, Kira T, Ogama H, Hozumi K (1963) Self-thinning in overcrowded pure stands under cultivated and natural conditions. J Biol Osaka City Univ 14:107-129

Zhang J, Zhou Y, Zhou G, Xiao CW (2013) Structure and composition of natural Gmelin larch (Larix gmelinii var. gmelinii) forests in response to spatial llimatic changes. PLoS One 8(6):e66668

Zhou FY (2017) Relationships among DBH, crown width and stand age of Pinus sylvestris var. mongolica plantation in sand land. Protect For Sci Tech 2:19-21

Zhou J, Lin GH (2018) Will forest size structure follow the -2 power-law distribution under ideal demographic equilibrium state? J Theor Biol 452:17-21

\section{Submit your manuscript to a SpringerOpen ${ }^{\circ}$ journal and benefit from:}

- Convenient online submission

- Rigorous peer review

- Open access: articles freely available online

- High visibility within the field

- Retaining the copyright to your article

Submit your next manuscript at $\boldsymbol{\nabla}$ springeropen.com 